\title{
Year and genotype effects on the fruit physico- chemical traits of sweet cherry cultivated under Southern Mediterranean climate in Morocco
}

\author{
Mina El Baji ${ }^{1.2}$, Zineb Nohaissi ${ }^{2}$, Said En-Nahli ${ }^{2}$, Hafida Hanine ${ }^{2}$, and Ossama Kodad ${ }^{1 *}$ \\ ${ }^{1}$ Laboratory of Bioprocess and Bio-Interfaces, Faculty of Science and Technology, Beni Mellal, \\ Morocco \\ ${ }^{2}$ Departement d'Arboriculture Viticulture. Ecole Nationale d'Agriculture de Meknès. Maroc
}

\begin{abstract}
The aim of the present work was the evaluation of genotype and year effects on some physico-chemical parameters of five sweet cherries grown in Middle Atlas of Morocco. The analysis of variance showed significant effects of the genotype, year and their interaction on all fruit physico-chemical traits focused. 'Coeur de pigeon' and 'Burlat' produced the heaviest fruit, whereas 'Van' and 'Coeur de pigeon' fruits were sweeter than others varieties Differences among the three years were highly significant (at $p<0.001)$ for all parameters highlighting the annual influence on the fruit quality parameters. Year effect was significant on the physicochemical fruit traits confirming the climatic conditions effect on fruit quality. Fruits harvested in 2016 and 2017 showed the highest values in terms of physico-chemical traits studied.
\end{abstract}

\section{Introduction}

Sweet cherry (Prunus avium L.) is deciduous fruit tree belonging to the genus Prunus, Rosaceae family, and is regarded one of the most important fruit crops within temperate area of the world [1]. In Morocco, sweet cherry was introduced previous to 1920 by the French protectorate and it was propagated by grafting and also by the seeds in middle Atlas Mountains regions of Morocco. The sweet cherry occupies acreage of around 4000 ha, with an annual production higher than 14,100 tons. The plantation area of this species is limited to medium and high altitude (idle and high mountain atlas) to satisfy the high-chill requirements required to break down dormancy of the introduced varieties. The most popular sweet cherry cultivars grown in Morocco are 'Bigarreau Van' and 'Bigarreau Burlat', with 'Napoleon' as pollinizer [2,3]. However, there are other cultivars grown at a small scale such as 'Cerisette' and 'Coeur de pigeon' [2].

During the last decade, the production of sweet cherry has increased significantly and new orchards are planted in the middle atlas area because of favourable climatic conditions

\footnotetext{
Corresponding author: $\underline{\text { osama.kodad } @ \text { yahoo.es }}$
} 
and availability of water for irrigation. Cool nights and template days during the fruit growing period generate suitable conditions for growing high-quality cherries in this area. For the new orchards, in spite of the lack of winter chill observed these last year's [3], the growers continue planting 'Bigarreau Van' and 'Bigarreau Burlat'. Other producers have decided to recuperate and plant some older cultivars such as 'Coeur de Pigeon' and 'Cerisette' introduced during the protectorate period [2]. However, few data about the chill requirement and fruit quality of these varieties are available for the growers for a bitter management of the orchards. In addition, the accelerated global warming and climate change affecting Morocco [4], including the middle atlas region, could affect negatively the agronomical behavior of these varieties.

Cherry fruit quality has been referred especially to the fruit size and firmness, while these parameters are only a part of quality definition [5]. In fact, fruit size is a determining factor in the choice of the cultivar [6]. Fruit firmness is also an essential attribute of quality (Esti et al., 2002), being considered a key aspect for marketing of cherries [7]. These characters depend on the genotypes [8], and influenced by the environment conditions. Finally, the chemical profile of sweet cherries largely influences the quality of the fruits and the preferences of consumers [9]. Titratable acidity (TA) and Total soluble solids (TSS) are important parameters to determine the adequate harvesting period [10].

The aim of this study was to evaluate the effect of genotype and year on the physicochemical quality of five sweet cherry cultivars grown in the Middle Atlas Mountains during three consecutive years.

\section{Material and Methods}

\subsection{Plant material}

Fruits from the five sweet cherry cultivars 'Burlat', 'Coeur de pigeon', 'Napoleon', 'Cerisitte' and 'Van' were harvested in commercial orchards situated at Imouzzer Kander city in the Middle Atlas region, at the optimum commercial maturity stage based on fruit maturity and colour development during May and June of three consecutive seasons (20152017). Thirty-year-old trees were studied. Trees grafted on S164 rootstock (Prunus mahaleb) and were planted on a loamy-clay soil at $4 \times 6 \mathrm{~m}$ spacing, drip irrigated and trained according to open vase system. The trees were chosen based on trunk diameter to ensure homogeneity among trees. The experiment was carried out during three consecutive seasons (2015-2017). The weather data collected from meteorological stations located near to the field were used to characterize climatic conditions.

\subsection{Physical Analyses}

At the maturity, 15 fruits per trees of both cultivars were harvested randomly around the canopy and were immediately brought back to the laboratory. The fruits were harvested at commercial stage according to the colour of each variety. The physical parameters studied were: fruit weight $(\mathrm{FW})$, fruit length $(\mathrm{FL})$, fruit width (FWi), nut weight $(\mathrm{NW})$, fruit firmness (Ffir), flesh width (FWe) and the firmness of the flesh fruit $(\mathrm{N})$. The linear parameters were measured using a digital caliper with $0.01 \mathrm{~mm}$ sensitivity. Fruit and nut weight was measured using an electronic balance with $0.01 \mathrm{~g}$ sensitivity. The firmness of the fruit was evaluated by maximum compression force in the equatorial region of the fruit using an electronic firmness tester (AGROSTA ${ }^{\circledR} 100$ Field digital firmness tester).

\subsection{Chemical Analyses}


These included total soluble solids (TSS, ${ }^{\circ}$ Brix), titratable acidity (TA, g malic acid/l), $\mathrm{pH}$ and maturation index (MI). TSS was determined with a digital refractometer. TA was determined by potentiometric titration with $0.1 \mathrm{~N} \mathrm{NaOH}$ up to $\mathrm{pH} 8.1$, using $10 \mathrm{~mL}$ of juice in $50 \mathrm{~mL}$ distilled water(IFU, 1996). The $\mathrm{pH}$ value was measured using a digital $\mathrm{pH}$-meter. MI was calculated as the ratio between TSS and TA (Fellers 1991).

\subsection{Statistical Analyses}

Statistical analyses were performed by the SAS software (SAS Institute Inc., 1988), using analysis of variance (ANOVA). Significant differences of means were analyzed using the Duncan's multiple range test.

\section{Results and Discussion}

\subsection{Genotype and year effects on physical fruit traits}

The statistical analysis revealed the significant effects of the genotype and the year on the fruit and nut physical traits evaluated (Table 1). The fruit weight varied between $6.5 \mathrm{~g}$ for 'Burlat' and 4.32g for 'Cerisette' (Table 2).

Table1. Analysis of variance for physical fruit and nut traits of 5 sweet cherry cultivars

\begin{tabular}{|l|c|c|c|c|c|c|c|}
\hline \multirow{2}{*}{ Source of variation } & & \multicolumn{7}{|c|}{ Mean square } \\
\cline { 3 - 8 } & df & FW (g) & FL (mm) & FWi (mm) & FFir (N) & FWe (mm) & NW (g) \\
\hline Genotype & 4 & $80.61^{*}$ & $315.8^{*}$ & $251.12^{*}$ & $107.3^{*}$ & $65.8^{*}$ & $0.07^{*}$ \\
\hline Year & 2 & $58.06^{*}$ & $86.6^{*}$ & $146.26^{*}$ & $32.28^{*}$ & $63.2^{*}$ & $0.46^{*}$ \\
\hline Genotype x year & 8 & $26.67^{*}$ & $42.3^{*}$ & $65.77^{*}$ & $15.94^{*}$ & $24.5^{*}$ & $0.04^{*}$ \\
\hline Error & 361 & 0.43 & 1.18 & 1.28 & 0.62 & 0.55 & 0.001 \\
\hline
\end{tabular}

* Significant at $\mathrm{P}<0.001$

Over the three years of study the 'Burlat' and 'Coeur de Pigeon' showed the heaviest fruit (Table 2), whereas 'Cerisitte' had the smallest value for fruit weight (Table 2). The varieties 'Burlat' and 'Van' cultivars are considered the important varieties planted in the new commercial orchards planted in Morocco. The fruit weight of 'Van' $(5.81 \mathrm{~g})$ was significant different and lower than that of 'Burlat' (6.5g) (Table 2). Similar results were reported by Pérez-Sánchez et al. [10] for these varieties grown under Spanish climatic conditions. 'Cerisitte' and 'Coeur de pigeons' are traditional French cultivars introduced into the Moroccan system production to offer a wide range of choices for growers. The fruit weight of Coeur de pigeon is similar to that recorded in 'Burlat', whereas 'Cerisitte' produce small fruit (Table 2). In sweet cherry, the fruit weight is transmitted quantitatively [8], and its expression depends primarily on the genotype [11].

The mean value of fruit length varied between $20.81 \mathrm{~mm}$ for 'Burlat' and $15.59 \mathrm{~mm}$ for 'Cerisitte' (Table 2). Fruit length and width of 'Burlat' and 'Coeur de Pigeon' were higher than those of others studied varieties (Table 2). During the three years of study, the fruits of 'Van' ware longest and largest than those of 'Burlat'. These results are in accordance with those reported in the literature [10,12]. The fruit flesh width of 'Burlat', 'Coeur de Pigeon' and 'Van' was similar (Table 2). (Table 2). For te fresh market, consumers prefer sweet cherries with large flesh [10]. 'Napoleon' cultivar was planted by the growers because of the intermediate flowering date that overlap the blooming period of 'Burlat' and 'Van' and 
is considered by the growers a good pollen donor in the orchards. However, the fruit of 'Napoleon' is not appreciated by the consumers because of the size and yellow color of the skin.

Table 2. Mean value of physical fruit traits of five sweet cherry grown under Middle Atlas Mountains.

\begin{tabular}{|c|c|c|c|c|c|c|c|}
\hline Variety & Year & FW & $\mathrm{FL}$ & FWi & FFir & $\mathrm{FWe}$ & $\mathrm{P} \mathrm{N}$ \\
\hline \multirow{4}{*}{ Burlat } & 2015 & $6.77 b^{*}$ & $20.76 \mathrm{~b}$ & $23.21 \mathrm{~b}$ & $5.81 \mathrm{~b}$ & $8.46 \mathrm{a}$ & $0.21 \mathrm{a}$ \\
\hline & 2016 & $8.61 \mathrm{a}$ & $23.56 \mathrm{a}$ & $25.33 \mathrm{a}$ & $6.33 \mathrm{a}$ & $8.68 \mathrm{a}$ & $0.43 b$ \\
\hline & 2017 & $4.15 \mathrm{c}$ & $18.12 \mathrm{c}$ & $18.55 \mathrm{c}$ & $3.82 \mathrm{c}$ & $5.28 b$ & $0.25 \mathrm{a}$ \\
\hline & Mean & 6.51 & 20.81 & 22.36 & 5.32 & 7.47 & 0.29 \\
\hline \multirow{4}{*}{ Cerisitte } & 2015 & $5.11 \mathrm{a}$ & $16.92 \mathrm{a}$ & $21.72 \mathrm{a}$ & $5.84 \mathrm{a}$ & $6.98 \mathrm{a}$ & $0.33 c$ \\
\hline & 2016 & $3.78 \mathrm{c}$ & $15.91 \mathrm{~b}$ & $19.11 \mathrm{~b}$ & $4.77 \mathrm{c}$ & $4.35 \mathrm{c}$ & $0.38 \mathrm{a}$ \\
\hline & 2017 & $4.08 \mathrm{~b}$ & $14.86 \mathrm{c}$ & $19.44 \mathrm{~b}$ & $4.95 \mathrm{~b}$ & $5.94 \mathrm{~b}$ & $0.36 \mathrm{~b}$ \\
\hline & Mean & 4.32 & 15.89 & 20.09 & 5.19 & 5.76 & 0.36 \\
\hline \multirow{4}{*}{ Couur de pigeon } & 2015 & $6.58 \mathrm{a}$ & $21.43 \mathrm{a}$ & $22.85 \mathrm{a}$ & $7.51 \mathrm{a}$ & $7.95 \mathrm{a}$ & $0.25 b$ \\
\hline & 2016 & $6.54 \mathrm{a}$ & $20.27 \mathrm{~b}$ & $22.16 \mathrm{~b}$ & $5.38 \mathrm{~b}$ & $7.87 \mathrm{a}$ & $0.32 \mathrm{a}$ \\
\hline & 2017 & $6.23 \mathrm{a}$ & $20.62 \mathrm{~b}$ & $21.70 \mathrm{c}$ & $5.43 \mathrm{~b}$ & $6.98 \mathrm{~b}$ & $0.25 \mathrm{~b}$ \\
\hline & Mean & 6.45 & 20.77 & 22.24 & 6.11 & 7.60 & 0.27 \\
\hline \multirow{4}{*}{ Napoleon } & 2015 & $4.70 \mathrm{a}$ & $20.66 \mathrm{a}$ & $18.55 \mathrm{a}$ & $4.80 \mathrm{a}$ & $6.56 \mathrm{a}$ & $0.26 \mathrm{c}$ \\
\hline & 2016 & $4.59 b$ & $19.54 \mathrm{c}$ & $17.72 \mathrm{c}$ & $4.77 \mathrm{a}$ & $6.01 \mathrm{~b}$ & $0.34 \mathrm{a}$ \\
\hline & 2017 & $4.34 \mathrm{c}$ & $20.13 b$ & $18.16 \mathrm{~b}$ & $4.29 \mathrm{~b}$ & $5.33 \mathrm{c}$ & $0.30 \mathrm{~b}$ \\
\hline & Mean & 4.55 & 20.11 & 18.15 & 4.62 & 5.96 & 0.30 \\
\hline \multirow{4}{*}{ Van } & 2015 & $5.41 \mathrm{c}$ & $19.58 b$ & $21.86 \mathrm{~b}$ & $7.24 \mathrm{c}$ & $7.55 \mathrm{~b}$ & $0.22 \mathrm{~b}$ \\
\hline & 2016 & $6.93 \mathrm{a}$ & $21.01 \mathrm{a}$ & $23.42 \mathrm{a}$ & $8.14 \mathrm{a}$ & $8.27 \mathrm{a}$ & $0.38 \mathrm{a}$ \\
\hline & 2017 & $5.05 \mathrm{~b}$ & $18.94 \mathrm{c}$ & $20.76 \mathrm{c}$ & $7.69 \mathrm{~b}$ & $7.01 \mathrm{c}$ & $0.23 b$ \\
\hline & Mean & 5.80 & 19.84 & 22.01 & 7.69 & 7.61 & 0.28 \\
\hline
\end{tabular}

*Different and same small letters indicate significant $(\mathrm{P}<0.05)$ and no significant differences $(\mathrm{P}>0.05)$, respectively, between the means according to Ducans's test.

Fruit flesh firmness is the most important trait to evaluate sweet cherry quality for the fresh market. 'Van' fruits had high firmness $(7.69 \mathrm{~N})$, flowed in decreasing level by 'Coeur de Pigeon' $(6.1 \mathrm{~N})$, 'Burlat' $(5.31 \mathrm{~N})$, 'Cerisette' (5.13 N) and finally 'Napoleon' (4.62 N) (Table 2). Interesting the firmness of 'Coeur de Pigeon' fruit found to be similar to that of 'Burlat' fruit. The firmness of 'Burlat' fruits was lower than that of 'Van' fruits. Similar results have been already reported under other climatic conditions [11]. In sweet cherry, the fruit firmness is related to the ripening period; higher fruit firmness was recorded in the late ripening cultivars [13].

Significant differences were obtained among the cultivars for stone weight (Table 1). 'Cerisette' showed highest nut weight $(0.35 \mathrm{~g})$, whereas 'Coeur de Pigeon' $(0.27 \mathrm{~g})$ and 'Van' $(0.28 \mathrm{~g})$ produced fruits with low stone weight (Table 2$)$. The analysis of variance showed significant differences among varieties for flesh width (Table 2). The mean value of flesh weight varied $5.75 \mathrm{~mm}$ for 'Cerisette' and $7.61 \mathrm{~mm}$ for 'Van' (Table 2). The 
varieties 'Van', 'Burlat' and 'Coeur de Pigeon' showed largest flesh width in comparison to that of 'Naopoleon' and 'Ceristette'.

The year effect was also significant for all studied traits (Table 1). Similar results have been reported in other cherry cultivars [14]. The mean values of fruit weight, length, and width were higher in 2016 than in 2015 and 2017 (Table 2). However, fruit firmness and fruit flesh width were higher in 2015. In sweet cherry, the final fruit size and weight is related to the cell length than to the numbers of cells [15]. Thus, climatic conditions and supply resources limitations affected more final cherry size during cell enlargement (stage III of fruit development) than cell division (during stage I) [16,17]. The data of rainfall registered in 2016 showed that the amount of precipitation during the May and June (corresponding to the stage III of fruit development) was higher than that registered in 2015 and 2017 during the same period (Table 3). Thus, the high values of fruit weight and dimension and fruit flesh width obtained in 2015 and 2016 might be due to the high rainfall registered during the period of fruit development in comparison to that recorded in 2017. However, the mean fruit firmness was lower during the rainfall year (2017) like that obtained during the drought year (2015). It has been reported that fruit firmness decrease with rainfall increasing [17]. These findings are in accordance with those obtained in the present study for the year 2015 and 2016. However, during 2015 (drought year) the fruit firmness was lower (Table 2). Sekse et al. [18] reported that during warm and sunny years the cherries produce softer fruits than the cold and rainy years. In 2017, the temperatures were higher $\left(2^{\circ} \mathrm{C}\right.$ of difference) than those registered during 2015 and 2016 (Table 3$)$. The warmer climate and drought stress recorded during fruit development in 2015 might explain the lowest value of fruit firmness obtained in this year.

Table 3. Mean temperature and total precipitation during the development period of the fruit in Imouzer Kander location.

\begin{tabular}{|l|c|c|c|c|c|c|}
\hline \multirow{3}{*}{ Months } & \multicolumn{3}{|c|}{ Temperature $\left({ }^{\circ} \mathrm{C}\right)$} & \multicolumn{3}{c|}{ Rainfall (mm) } \\
\cline { 2 - 7 } & 2015 & 2016 & 2017 & 2015 & 2016 & 2017 \\
\hline April & 20 & 21 & 25 & 58 & 41 & 46 \\
\hline Mai & 25 & 25 & 24 & 61 & 79 & 40 \\
\hline Juin & 27 & 27 & 30 & 32 & 22 & 14 \\
\hline Mean & 24 & 24 & 26 & 50 & 47 & 33 \\
\hline
\end{tabular}

The significance of the year $\times$ genotype interaction for all the physical parameters (Table 1) indicates that the magnitude of the variation from year to year depends on genotype. Several authors reported that physical fruit trait depends on the genotype $[8,10,12]$. In fact, the mean values of fruit weight and fruit fresh width were stable and high during the three years of study (Table 2), whereas for 'Burlat' and 'Van' these characters varied significantly from year to year (Table 2).

\subsection{Genotype and year effects on chemical fruit traits}

The analysis of variance showed a significant effect (at $P<0.001)$ of genotype and year on all chemical parameters (Table 4). The chemical parameters of the studied varieties are given in Table 5. The mean value of TSS varied between $9.85^{\circ}$ Brix for 'Burlat' and 16.51 'Brix for 'Coeur de Pigeon'. The fruit of 'Van', 'Coeur de Pigeon', 'Napoleon' and 
'Cerisitte' showed similar and significantly higher values of SSR than that of 'Burlat' fruits (Table 5).

Table 4. Analysis of variance of chemical fruit attribute of five sweet cherry cultivars

\begin{tabular}{|l|c|c|c|c|}
\hline & & \multicolumn{3}{|c|}{ Mean square } \\
\hline Source of variation & df & TSS & $\mathrm{pH}$ & TA \\
\hline Genotype & 4 & $161.11^{*}$ & $0.56^{*}$ & $81.77^{*}$ \\
\hline Year & 2 & $64.79^{*}$ & $0.32^{*}$ & $57.31^{*}$ \\
\hline Genotype x Year & 8 & $96.83^{*}$ & $1.80^{*}$ & $55.83^{*}$ \\
\hline Error & 15 & 24.04 & 0.10 & 11.46 \\
\hline
\end{tabular}

* Significant at $\mathrm{P}<0.001$

The mean value of TSS of 'Van' was significantly higher than that of 'Burlat' fruits during the three years of study (Table 5). These results are in accordance to that reported in others cherries [12,19]. However, higher values of TSS have been reported for 'Burlat' by Pérez-Sánchez et al. [10] under Spanish climatic conditions.

Table 5. Mean value of chemical parameters of five sweet cherry cultivars grown in Middle Atlas

\begin{tabular}{|c|c|c|c|c|}
\hline & & Mountains & & \\
\hline Variety & Year & TSS $\left({ }^{\circ}\right.$ Brix $)$ & $\mathrm{Ph}$ & TA (malic acid/l) \\
\hline \multirow{4}{*}{ Burlat } & 2015 & $9.88 b^{*}$ & $3.55 b$ & $6.30 \mathrm{~b}$ \\
\hline & 2016 & $12.10 \mathrm{a}$ & $3.09 \mathrm{c}$ & $8.11 \mathrm{a}$ \\
\hline & 2017 & $7.60 \mathrm{c}$ & $4.03 \mathrm{a}$ & $5.35 \mathrm{c}$ \\
\hline & Mean & 9.86 & 3.56 & 6.59 \\
\hline \multirow{4}{*}{ Cerisitte } & 2015 & $14.20 \mathrm{~b}$ & $3.55 \mathrm{a}$ & $9.77 \mathrm{c}$ \\
\hline & 2016 & $15.40 \mathrm{a}$ & $2.85 b$ & $14.47 \mathrm{a}$ \\
\hline & 2017 & $15.25 \mathrm{a}$ & $3.56 \mathrm{a}$ & $10.15 b$ \\
\hline & Mean & 14.95 & 3.32 & 10.46 \\
\hline \multirow{4}{*}{ Cœur de Pigeon } & 2015 & $12.35 \mathrm{c}$ & $3.30 \mathrm{~b}$ & $9.25 b$ \\
\hline & 2016 & $17.01 \mathrm{a}$ & $3.41 \mathrm{a}$ & $11.73 \mathrm{a}$ \\
\hline & 2017 & $20.20 \mathrm{~b}$ & $3.02 \mathrm{c}$ & $11.75 \mathrm{a}$ \\
\hline & Mean & 16.52 & 3.24 & 10.91 \\
\hline \multirow{4}{*}{ Napoléon } & 2015 & $14.95 b$ & $3.73 a$ & $5.56 \mathrm{c}$ \\
\hline & 2016 & $16.30 \mathrm{a}$ & $3.41 \mathrm{c}$ & $9.41 \mathrm{a}$ \\
\hline & 2017 & $14.10 \mathrm{c}$ & $3.65 b$ & $7.70 \mathrm{c}$ \\
\hline & Mean & 15.12 & 3.60 & 7.56 \\
\hline \multirow{4}{*}{ Van } & 2015 & $11.01 \mathrm{c}$ & $3.43 b$ & $7.20 \mathrm{c}$ \\
\hline & 2016 & $19.50 \mathrm{a}$ & $3.61 \mathrm{a}$ & $7.87 \mathrm{~b}$ \\
\hline & 2017 & $15.60 \mathrm{~b}$ & $3.07 \mathrm{c}$ & $11.60 \mathrm{c}$ \\
\hline & Mean & 15.37 & 3.37 & 8.89 \\
\hline
\end{tabular}

* Different and same small letters indicate significant $(\mathrm{P}<0.05)$ and no significant differences $(\mathrm{P}>0.05)$, respectively, between the means according to Ducans's test. 
Concerning the titratable acidity, the mean value fluctuated from $6.58 \mathrm{malic}$ acid/1 for 'Burlat' to 10.9 malic acid/l for 'Coeur de Pigeon' (Table 5). The values obtained in 'Coeur de Pigeon' and 'Cerisitte' were similar, 10.91 and $10.46 \mathrm{~g}$ malic acid /1, respectively. In the present study, 'Van' fruit showed highest value of titratable acidity than than of 'Burlat'. Similar resultants have been reported for these varieties [12]. The $\mathrm{pH}$ varied between 3.24 for 'Coeur de Pigeon' and 3.59 for 'Napoleon' cultivar (Table 5). The mean value of the $\mathrm{pH}$ of 'Burlat', 'Van' and 'Napoleon' were similar. At commercial harvesting $\mathrm{pH}$ of 'Burlat' was 4.21, whereas that of 'Van' was between 3.6 and 3.82[19]. In the present study, the values are lower than those reported in the literature, probably due to a different date level of ripening at harvest and growing conditions.

The year effect was significant for all the chemical parameters (Table 5). Similar results were reported in others cherries [20, 21]. The mean values of TSS were higher in 2016 as compared to the other two years (Table 6). Cherries produced in 2016 and 2017 contained the highest total soluble solids and titratable acidity (Table 5). However, in 2015 the different varieties produced fruit with lowest TSS and titratable acidity (Table 5). These differences might be attributed to the climatic variations registered during 2015-2017 (Table 3). In 2015, the climatic conditions were extreme during fruit developing (high temperature and drought stress) which probably affected the chemical attribute of fruit.

The analysis of variance showed that year $\times$ genotype interaction was significant for all chemical attributes (Table 4) indicating that the magnitude of the variation from year to year depends on genotype. Similar results were reported for sweet cherry [21]. 'Cerisitte' cultivar produced fruits with stable weight and flesh width mean values during the years of study (Table 5), whereas the others varieties showed high variability of these traits among the years (Table 5).

\section{Conclusions}

The results obtained in the present work confirm the negative effect of extreme climatic conditions on the expression of fruit traits in sweet cherry. Significant influences of the year and the genotype on the quality of cherry fruits produced under climatic conditions of Morocco were observed. Fruits produced in 2016 and 2017 were heavier and sweeter than those produced in 2015. The high temperature and drought stress (lack of rainfall) might be related to the low values of physico-chemicals traits of the studied varieties obtained in 2015. However, the behavior of the varieties was different from year to year. The present results indicate that additional studies should be carried out in the future, including other varieties, to establish fruit growth models that could allow producers to predict the ripening period of the fruit according to the evolution of temperatures during the fruit growth period.

\section{References}

1. H.Demirsoy, L. Demirsoy. Fruits,59, 219-223 (2004)

2. A.Oukabli, Bull. Trans. Tech, 114 (2004)

3. O. Kodad, S. En-Nahli, H. Hanine, M. El Baji, Agriculture du Maghreb,97, 62-63 (2016)

4. M. Benassi. Options Méditerr: A Sémin Méditerr,80, 83-86 (2008)

5. S. Predieri, R. Dris, F. Rapparini, Food, Agric. Envi,2, 307-309 (2004)

6. A. Oukabli, M. Laghezali, Fruits,55(1), 83-92 (2000)

7. E.D. Cittadini, Sweet cherries from the end of the world: Options and constraints for fruit production systems in South Patagonia, Argentina. The Netherlands. Wagening en University. 20-29 (2007)

8. P. E.Hansche, V. Beres, R. M. Brooks, P. Am. Soc. Hortic. Sci,88, 173-183 (1966) 
9. M. Fazzari, L. Fukumoto, G. Mazza, M.A. Livrea, L. Tesoriere, L. Di Marco, J. Agric. Food Chem,56, 3561-3568 (2008)

10. R. Pérez-Sánchez, M.Á. Gómez-Sánchez, Mr. Morales-Corts, J. Food Qual,33, 490$506(2010)$

11. B.Gonçalves, J. Moutinho-Pereira, A. Santos, A. Paula Silva, E. Bacelar, C. Correia, E. Rosa, Tree Physiology,26, 93-104(2006)

12. K. Vursavus, H. Kelebek, S. Selli, J. Food Engin,74, 568-575 (2006)

13. V. Usenik, D. Kastelec, F. Štampar, Food Chemistry,90, 663-671 (2005)

14. A.Khadivi-Khub, Trees 28: 669-685(2014)

15. J.W. Olmstead, A.F. Iezzoni, M.D. Whiting. J. Ame. Soc. Hort. Sci, 132, $5697-$ 703(2007)

16. V. Blanco, P.J. Blaya-Ros, R. Torres-Sánchez, R. Domingo, Plants . 9, 942020

17. J. Blažková, I. Hlušičková, J. Blažek. Hortic. Sci. (Prague), 29, 92-98 (2002)

18. L. Sekse, M. Meland, T. Reinsnos, S. Vestrheim, Euro. J. Hortic. Sci, 74(6),268-274 (2009)

19. A.A. Hayaloglu, N.Demir, J. Food Sci,80,564-570 (2015)

20. R.Kurlus, J. Fruit. Orn. Plant. Res, 12, 35-39 (2004)

21. J. Neilsen, D. Neilsen, F. Kappel, T. Forge, Hortscience,49, 215-220. (2014) 